\title{
Application of Geographic Information Systems to Assessing the Dynamics of Slum and Land Use Changes in Urban Core of Akure, Nigeria
}

\author{
Ayo Emmanuel Olajuyigbe ${ }^{1}$, Olusola Olalekan Popoola ${ }^{1}$, Suleiman Abdul-Azeez Adegboyega ${ }^{2} \&$ Tayo \\ Obasanmi ${ }^{1}$ \\ ${ }^{1}$ Department of Urban and Regional Planning, School of Environmental Technology, Federal University of \\ Technology, Akure, Nigeria \\ ${ }^{2}$ Department of Remote Sensing and GIS, School of Earth and Mineral Sciences, Federal University of \\ Technology, Akure, Nigeria \\ Corresponding author: Ayo Emmanuel Olajuyigbe, Department of Urban and Regional Planning, School of \\ Environmental Technology, Federal University of Technology, Akure, Nigeria. Tel: 234-80-3711-7606. E-mail: \\ olajuyigbe03@yahoo.com
}

Received: January 18, 2015 Accepted: January 22, 2015 Online Published: July 29, 2015

doi:10.5539/jsd.v8n6p311 URL: http://dx.doi.org/10.5539/jsd.v8n6p311

\begin{abstract}
Ancient city centres are characterised by inadequately planned/unplanned land use and unsecured tenure system, leading overtime to the development of different forms and grades of slum in and around urban core area. This research studied the slum in the urban core of Akure, Nigeria deploying tools of Geographic Information System for comprehensive analysis of slum peculiarity for guiding action. Descriptive and analytical methods based on field survey and extraction of information from satellite images were utilized. The study examined the existing situation in the study area in terms of its housing system, conditions of infrastructure, socio-economic status of respondents and adequacy of livelihood with respect to slum indicators as defined by UN-Habitat (2003). The study revealed specific areas of higher degree of slum conditions and a representation of level of changes in land uses. Another finding shows high rate of conversion, mainly from residential land uses to other uses as the major characteristic of land use changes in the area. Poverty has constituted a dominant factor for continued existence of slum conditions due to paucity of employment opportunities. The study further discovered diverse manifestations of slums within a locality attributed to factors such as strong family linkages, structure of property ownership and high level of economic dependency. Economic empowerment through aids and supports for Small Medium Enterprises (SMEs), development of market network strategy for Akure and development of a comprehensive land use plan that would ensure sustainable growth of the city core area are canvassed.
\end{abstract}

Keywords: infrastructure decay, decay severity mapping, slum characterization, urban core, slum indicators, Geographic Information System

\section{Introduction}

The decay in the built environment in many developing countries, Nigeria inclusive, is widespread. The factors responsible can be traced to rapid urbanization, rural-urban migration, steady economic downturn, decay of urban infrastructure, poor quality of original construction, lack of integrated planning, negligent urban housekeeping, inadequate methods of preservation of historic value, disaster and war (Omole, 2000; World Bank, 2005; Omole \& Owoeye, 2006; Ahiamba, Dimuna \& Okogun, 2008). This decay manifests in different forms, including squalor, squalid, blight, slum etc. The urban core of Akure exhibits such deplorable conditions where substandard houses are prevalent in unkempt environment (Owoeye, 2006).

Among factors that contribute to the continued formation and expansion of slums, include rapid rural-to-urban migration, policy failure, increasing urban poverty and inequality, population growth and globalisation. While more people are migrating from rural areas to towns and cities, urban areas are not expanding enough, inadequate affordable houses, and municipalities are not able to provide enough accommodation. Other factors are failed government policies, corruption, inappropriate regulation, dysfunctional land markets, and unresponsive financial systems to provide low-income people with essential public infrastructure and services (UN habitat, 2003). 
Kengne (2000) argued that there is a close correlation between the informal economy and informal settlement. Another important factor that helps to explain the proliferation of slums is the rigidity of urban planning regulations associated with other factors such as poor governance, corruption, and nepotism, which all lead to a severe shortage of land and urban housing, squatting, and infringements of building regulations (Fekade, 2000).

A slum according to UN-HABITAT (2007) is an area that combines, to various extents, the following characteristics: inadequate access to safe water, inadequate access to sanitation and other infrastructure, poor structural quality of housing, overcrowding and insecure residential status. These characteristics are being proposed because they are largely quantifiable and can be used to measure progress toward the Millennium Development Goal to significantly improve the lives of at least 100 million slum dwellers by 2020 (UN-HABITAT, 2007).

Slums manifest in different ways and vary from country to country. Two major ones have been identified. These are slums of hope or progressing settlements and slums of despair or declining neighbourhoods. The first is made of 'old' city centre slums and 'new' slum estates whilst the latter is made of squatter settlements and semi-legal sub-divisions (UN- Habitat, 2003). These two major ones are sub divided into four categories of slums. These are inner city slums; slum estates, squatter settlements and illegal sub-divisions which differ in terms of their formation, condition and extent of deprivation.

Recently, Abebe (2011) described informal settlements into three phases namely infancy, consolidation and saturation based on the availability of open space in the neighbourhood. According to Abebe (2011), infancy is the starting stage at which 50 percent of the settlement area would be built-up; consolidation stage refers to booming stage at which up to 80 percent of the land would be used for housing construction; and saturation stage is the stage whereby further construction is mainly continued through vertical densification.

Urban land uses and their areal distributions are fundamental data required for a wide range of studies in the physical and social sciences, as well as by municipalities for land planning purposes (Stefanov, 2001). To this end, geographic information systems (GIS) and remote sensing data and techniques provide efficient methods for analysis of land use issues and tools for land use planning and modelling. Understanding the driving forces of land use development in the past, managing the current situation with modern GIS tools, and modelling the future will help to develop plans for multiple uses of natural resources and nature conservation. Fortifying data from GIS techniques and applications with the regular field survey/research approaches can lead to greater accuracy and efficiency in solving myriads of social and environmental concerns. These include delineating land use changes, slum development, identifying causative factor for slum development, observing the trend of land use changes (to forecast future trends) and also in identifying solutions to the attendant problems of slum and urban decay generally.

Remote Sensing and GIS has been applied severally for change detection of informal settlements and exploiting spatial patterns (Hurskainen \& Pellikka, 2004; Stasolla \& Gamba, 2007; Abbott, 2003; Sartori, Nembrini \& Stauffer, 2002). The Object-based Image Classification (OBIA) approach has been employed for detecting and mapping slum settlements through the integration of semantic information (Benz et al., 2004; Hofmann, 2001; Nobrega, Quintanilha \& Ohara, 2006).

In many countries, local authorities have limited understanding of the slum location, extent and their dynamics. Given the expected increase in the number of slum dwellers, there is also a growing need for efficient methods to effectively identify and monitor slums and informal developments (Sliuzas, Mboup \& de Sherbinin., 2008). Reliable spatial information about informal settlements is vital for any action of improvement of the living conditions (Hofrnann et al., 2008). Over the years, several approaches have been used to detect slums. These include the participatory approach as used by Karanja (2010), the livelihood approach, and the census data approach as used by Weeks, Hill, Stow, Getis and Fugate (2007).

These current practices in spatial analysis related to slums are based on simple aggregations of slum household data according to Enumeration Areas (EAs) in which the households reside. Any EA in which more than 50\% of the population is deprived in terms of one of the four operational slum indicators of the UN Habitat is considered a slum (Sliuzas et al., 2008). This approach of spatially defining slums has been adopted out of pragmatic considerations largely relating to available data. This often results in several problems since variables or characteristics specific to the settlement level such as condition of the roads, drainage, air pollution, and location are not considered (Sliuzas et al., 2008). Traditional methods like statistical, regional analyses and fieldwork are limited to capture the urban process (Niebergall, Leow \& Mauser, 2007). Informal settlements are highly dynamic and therefore require an alternative approach and a reliable procedure for detection and monitoring. Hofmann (2008) acknowledges that remote sensing and image analysis can certainly contribute to monitoring 
the spatial behaviour of the informal settlements. Remotely sensed data provide spatially consistent datasets that cover large areas with both high detail and high temporal frequency (Herold, Clarke \& Seepan, 2001).

This study adopted the core ideas of the land use models, to better understand and manage the integration of existing socio-economic information and geographical information. In addition, the central place theory was adopted to understand that urban core serves as a central place for the surrounding areas, and assesses resultant forces. Although, there are several ranges that limit demand and pressure of population of urban core, yet the urban core is continually under pressure of traffic congestion, population, and concentration of unemployed people. This research intends to exercise this fortification and discover the causes and solution to slum developments in Akure, Ondo State, Nigeria.

\section{Research Methodology}

\subsection{The Locale}

The study area is the core area of Akure, Nigeria (Figure 1). Akure is a medium-sized traditional Nigerian city and it existed long before the advent of British colonial rule in Nigeria. The city is situated in the South-western part of Nigeria. It lies approximately on latitude $7^{\circ} 15^{\prime}$ North of the Equator and longitude $5^{0} 05^{\prime}$ East of the Greenwich Meridian and became the provincial headquarters of Ondo province in 1939 and the capital city of Ondo State and Akure Local Government Council Headquarters in 1976 (Akinbamijo, 2006; Olujimi \& Bello, 2009; Ayeni \& Ebohon, 2012; Ayeni, 2012). Consequently, there is heterogeneous massing of people and activities in the city.

The rapid growth of the city, particularly within the last 25 years, has made it one of the fastest growing metropolitan areas in the South-western Nigeria. Its population has more than tripled from 157,947 in 1990 to about 500,000 in 2006 [National population Commission (NPC) reports, 2006]. Since its pronouncement as the administrative and economic seat to Akure South Local Government Authority, and Ondo State in 1976, the city has witnessed immense growth in the size of built-up areas, number of immigrants, transportation, and commercial activities.

The study was conducted in three slum communities in the city; Araromi, Isolo and Igboyegun respectively. These localities have exhibited many slum attributes when viewed from satellite imagery and hence its selection for this study. The attributes include haphazard arrangement of structures, lack of or poor road network, lack or inadequate air space between buildings, irregular land sub-division pattern, high building density, small building sizes, little or no vegetation (Figure 2).

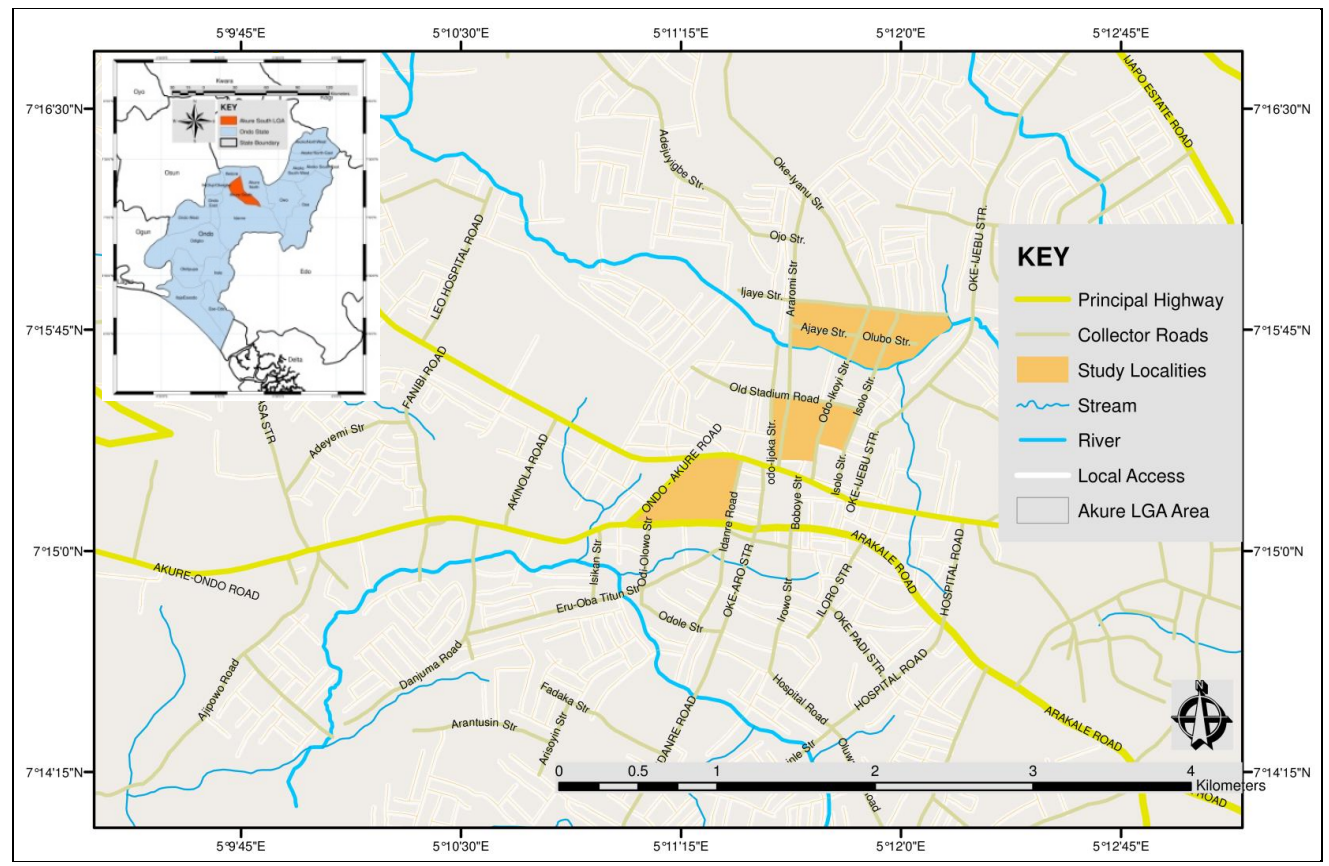

Figure 1. The study area within Akure

Source: Authors, 2013. Developed from Shapefiles of administrative areas subdivision for Nigeria as produced by IITA (2011) (insert; Akure within Ondo state, Nigeria) 


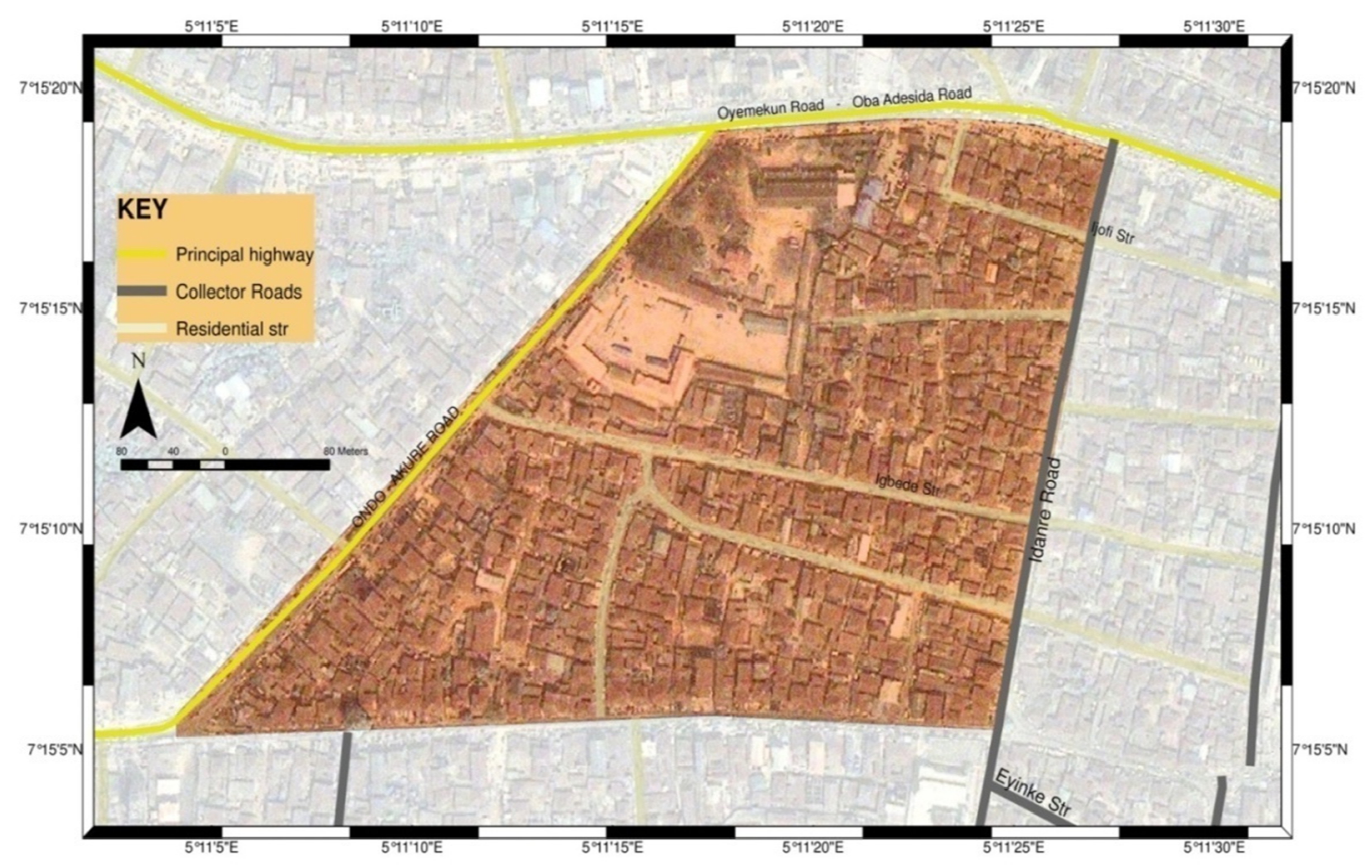

Figure 2. Poor accessibility and haphazard arrangement of structures

Source: Google, 2010 (with authors' modifications in Arcmap 9.3)

\subsection{The Database}

Primary data used in the research include data obtained using survey questionnaires and satellite images of the study area. The survey questionnaires focused on the five (5) indicators: access to improved water, access to improved sanitation, security of tenure, durability of housing, sufficient living area and socio-economic characters of the area for defining slum. Qualitative data, in the form of recent satellite imageries, was also used. In addition, relevant information was extracted from existing and related studies on the subject matter and study area. The selected neighbourhoods serve as sample frame boundaries for the research, in which the individual house units are the sample units. Study localities were selected because they have slum attributes. The study localities are Araromi/Odo-Ikoyi, Isolo and Igboyegun. The research population is the number of buildings in the area. Araromi/Odo-Ikoyi, Isolo and Igboyegun have 287, 266 and 275 buildings respectively. In determining the sample size, the formula developed by Israel (2009) $\mathrm{S}=\mathrm{N} /\left\{1+\mathrm{N}(\mathrm{e})^{2}\right\}$ was adopted. This gives sample sizes of 93, 87 and 90 for the 3 localities respectively. The total sample size is the addition of samples sizes of the three localities, which totalled 270 housing units. The sampling exercise adopted both stratified sampling and systematic random sampling techniques successively. First, the study population was divided into the different strata, namely; Araromi/Odo-Ikoyi, Isolo and Igboyegun area respectively. Then systematic random sampling technique was adopted in the administration of questionnaires in each of the localities. Statistical Packages for Social Sciences (SPSS) was used to carry out statistical (both descriptive and inferential) analysis on survey data.

In estimating land use change dynamics, this study adopts the approach of Post-Classification Comparison Analysis, of satellite imagery, as suggested by Musaoglu, Kaya, Seker and Goskel, (2002) and utilised by Oyinloye and Kufoniyi (2013), in detecting land use changes in Ikeja Government Residential Area (GRA), Nigeria. Ramadan, Peng and Cheng, (2004) also used the approach in Shaoxing City in China. Questionnaires were used to gather information on changes in land use in the study area over the years by asking residents and property owners, relevant questions on categories of uses they have put their buildings to, since year 2006. Compilation of such information and its validation with knowledge on the area from older generation in the area formed the information base on land use changes. This information gathered verbally and via questionnaires, was transformed as attributes into map form with the use of ArcGIS.

In developing the slum map (decay severity map), year 2012 GOOGLE image of the study area was useful for the characterization and classification. The Satellite imageries were obtained through GPSMapEdit 2.0 server on a $5 \mathrm{~m}$ resolution. It was made to pass through process of image enhancement and geo-referencing. The study localities were delineated as subset of the image. The image was digitized on ArcMap 9.3 platform in thematic of 
roads, structures, and other features. Supervised image classification was then performed on false-colour composites into the following land uses: residential, commercial, mixed use, public, industrial and open spaces. Attributes database was created for the images and the characteristics (features) of each structure were entered into the database per year. Distribution of the changes in various land uses over the years was highlighted in the false-colour composite through changes in the attributes of each land uses, which reflects in the colour composite. That is, as the land uses change their attributes changes. The changes in attributes are automatically reflected in the false-colour composite image for each year-period considered.

The slum defining threshold which include use of building, age of building, availability and accessibility of portable water, room occupancy ratio, availability and accessibility of toilet facilities, were also inputted into the database platform per building structure, with each indicator being scored a mark. These attributes were scored on a scale of 0 - 5 in relation to how adequate the facilities were, while a zero score indicates unavailability. Lower score indicates poor status of facility. The total score per building was entered into the database as decay severity score. This means that structures (buildings) with a score of five (5) are best and buildings with a score of zero (which indicates that such building does not have toilet, access to portable water, adequate per-room occupancy ratio, etc), this resulted in the characterization of the slum conditions (or severity) in the study area.

\section{Results and Discussion}

\subsection{Socio-Economic Traits}

Majority (60\%) of the respondents are male, $76.9 \%$ of respondents are married. Age distribution shows that $67.9 \%$ of respondents are in their productive ages (18 - 45 years). Other socio-economic characteristics of the study area are reported in Table 1.

Table 1. Socio-economic characteristics

\begin{tabular}{|c|c|c|c|}
\hline Variable & Igboyegun (\%) & Isolo (\%) & Araromi (\%) \\
\hline \multicolumn{4}{|l|}{ Education Level } \\
\hline No Education & 33.8 & 25.76 & 28.73 \\
\hline Adult Education & 9.86 & 3.03 & 0.1 \\
\hline Primary Education & 36.62 & 42.32 & 41.54 \\
\hline Secondary Education & 12.68 & 15.25 & 20 \\
\hline Post-Secondary Education & 7.04 & 9.09 & 10.77 \\
\hline \multicolumn{4}{|l|}{ Rent Per Month } \\
\hline N1001-N1500 & 36.99 & 33.82 & 12.12 \\
\hline N1501-N2000 & 45.21 & 60.29 & 37.08 \\
\hline N2001-N2500 & 16.44 & 5.88 & 50 \\
\hline N2501-N3000 & 1.37 & 0 & 0.7 \\
\hline \multicolumn{4}{|l|}{ Per Month Income } \\
\hline Below N10,000 & 39.13 & 43.94 & 36.92 \\
\hline N10,001-N15,000 & 52.17 & 31.82 & 36.9 \\
\hline N15,001-N20,000 & 4.35 & 19.7 & 21.56 \\
\hline N20,001-N25,000 & 1.45 & 0 & 4.62 \\
\hline N25001 and above & 2.9 & 4.55 & 0 \\
\hline \multicolumn{4}{|l|}{ Household Size } \\
\hline 1 person & 2.99 & 4.55 & 0.00 \\
\hline 2 persons & 5.97 & 0.00 & 17.19 \\
\hline 3-4 persons & 14.93 & 22.24 & 10.94 \\
\hline 5-7 Persons & 46.27 & 46.97 & 42.19 \\
\hline Above 7 persons & 29.85 & 24.24 & 29.69 \\
\hline \multicolumn{4}{|l|}{ Means of Waste Disposal } \\
\hline Bush Dumping /Dump Site & 32.84 & 6.45 & 9.38 \\
\hline Burning of waste & 32.8 & 29.03 & 64.52 \\
\hline Municipal waste Management & 67.16 & 64.52 & 57.81 \\
\hline Age of Building & & & \\
\hline
\end{tabular}




\begin{tabular}{lrrr}
\hline Variable & Igboyegun (\%) & Isolo (\%) & Araromi (\%) \\
\hline Less than 10yrs & 4.55 & 7.35 & 6.15 \\
10 - 20yrs & 18.18 & 22.06 & 10.77 \\
20 - 30yrs & 18.08 & 22.06 & 30.77 \\
30 - 40yrs & 212. & 19.12 & 40.00 \\
40 - 50yrs & 37.88 & 29.41 & 12.31 \\
\hline
\end{tabular}

Across the study localities, literacy level is low because about one-third of the population only had secondary education. The observed low level of education could undermine the importance of healthy living and environment. $40.5 \%$ of the respondents are unemployed while $32.4 \%$ of the respondents are self-employed. Lack of employment is a factor for proliferation of poverty, which is a sustaining factor of slum. Per month rent rate in the study area, ranges from $\$ 1,000$ to $\$ 3,000$. The highest rent level is observed in Araromi/Odo-Ikoyi where 50\% of residents pay above 2000 while at Igboyegun and Isolo over $80 \%$ and $90 \%$ of residents pay between 1000 and 2000 . This is an indication that socio-economic characteristics of slum dweller vary across locations.

Field survey revealed that over $90 \%$ of residents at Igboyegun and over $70 \%$ at Isolo and Araromi earn below the national average ( $\$ 17,000$ ). Lack of economic wherewithal reduces the desire of the people for improved living or better environment. In addition, rent is relatively high across the study area when considered in the light of the condition of majority of the buildings and the facilities provided in most houses. Despite government efforts at reducing indiscriminate dumping of refuse in the environment, $5.0 \%$ of dwellers in the study area still dump waste on dumpsites, which are usually within trekking distance from their homes, and close to other people's homes.

In agreement with the findings of Owoeye and Omole (2012) who reported that over half of the residents (65.3\%) make use of controlled tipping method, this study discovered a similar trend as more than half $(57.1 \%)$ of dwellers make use of the controlled tipping method provided by the government through the agency of Waste Management Authority. Yet, observation revealed that some 37.9\% who claim that they burn their wastes usually pack the unconsumed remnants, only to dump it into roadside drainages. This often leads to blockage of drainages which become breeding grounds for rodents, flies, rats, mosquitoes and other pathogens that contribute to the spreading of diseases and other related hazards in the environment. For example, the regular dumping of refuse in Ala River has led to seasonal flooding into the premises of buildings around the place (Owoeye and Omole, 2012).

About $30 \%$ of the respondents reside in the study area because it is close to their places of work, $27 \%$ because it is their personal building while $19 \%$ reside in the study area because they have free accommodation. The rest, $7 \%, 8 \%, 6.9$ and $2 \%$ are located within the study area for family/social ties, cheap rent, and unavailability of rentable rooms amongst other issues. It can be deduced that the main reasons for living in these areas are lack of willingness to leave their personal buildings and economic reasons.

\subsection{Slum Defining Threshold}

Wells/springs are the most common sources of water in the study area. However, it was discovered that most of the wells/springs, $56.52 \%, 45.45 \%$ and $50.75 \%$ across the study area are unprotected. Unprotected wells and springs are unimproved sources of water that give access to many water-borne disease and infections (UN-HABITAT, 2008).

Findings also revealed that $61.64 \%$ of houses at Igboyegun do not have access to improved sanitation (toilet), the value is higher for Isolo at $64.70 \%$, while at Araromi/Odo-Ikoyi area, $68.65 \%$ of houses do not have access to improved sanitation. Unimproved toilets give room for many health hazards. Inadequate sanitation, through its impact on health and environment, has considerable implications for economic development.

Reduced space per person is often associated with certain categories of health risks and therefore considered as key criteria to define the slum (UN-HABITAT, 2008). At Araromi/Odo-Ikoyi, 57.81\% reported that there are up to three (3) persons occupying one room. At Isolo and Igboyegun, $25.37 \%$ and $31.75 \%$ of the respondents reported three (3) persons per room. The most overcrowded situations are observed at Igboyegun where $36.51 \%$ reported cases of four (4) persons and above in one room. At Isolo and Araromi/Oke-Ikoyi, $10.45 \%$ and 20.31\% of such cases were reported. Based on the definitions by WHO (2005) and UN-Habitat (2008) that state that not more than two people sharing the same room, it can be deduced that more than one-third of dwellers in Igboyegun are living in overcrowded rooms, while $20.31 \%$ and $10.45 \%$ of Araromi and Isolo, respectively, are overcrowded. 


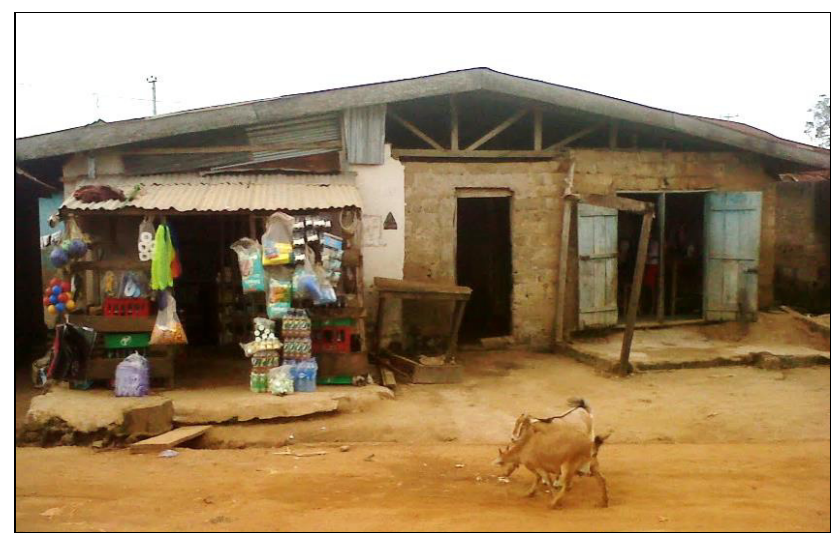

Plate 1. A residential cum commercial building in a state of disrepair at Isolo, Akure

Over $34 \%$ of the buildings in the study area are poor in terms of overall structural rating, $37.3 \%$ are fair while a scanty 0.3 are excellent. However, $25.7 \%$ are in good condition. This means that there is the need to urgently attend to the $2.6 \%$ of structures that are classified as dangerous in the study area. In addition, $71.4 \%$ of the structures classified as fair and poor needs to be upgraded.

Table 2. Slum defining characteristics

\begin{tabular}{lrrr}
\hline & Igboyegun (\%) & Isolo (\%) & Araromi (\%) \\
\hline Number of persons per room & & & \\
1 person & 7.94 & 7.94 & 0.00 \\
2 Persons & 23.81 & 38.10 & 44.62 \\
3 Persons & 31.75 & 36.51 & 49.23 \\
4 Persons & 36.51 & 11.11 & 0.00 \\
above 4 persons & 12.50 & 6.35 & 6.15 \\
Durability of Structure & & & \\
Dangerous & 10.0 & 1.47 & 0.0 \\
Poor & 2.86 & 45.59 & 40.30 \\
Fair & 24.29 & 42.65 & 37.31 \\
Good & 7.07 & 2.25 & 4.82 \\
Excellent & 1.43 & 0.0 & 0.0 \\
Toilet Facility & & & \\
No Toilet & 5.48 & 11.76 & 13.43 \\
Unventilated Pit/Bucket Latrine & 56.16 & 52.94 & 55.22 \\
Ventilated Pit/Bucket Latrine & 31.51 & 29.41 & 23.88 \\
Water Closet & 6.85 & 5.88 & 7.46 \\
Water Supply & & & \\
None & 8.70 & 7.58 & 14.93 \\
Unprotected well/spring & 56.52 & 45.45 & 50.75 \\
Protected well/spring & 39.13 & 45.42 & 31.34 \\
Public borehole & 4.35 & 0.00 & 0.00 \\
Pipe-borne Water & 0.00 & 0.00 & 0.00 \\
Building Accessibility & & & \\
No defined Access & 19.72 & 8.82 & 37.31 \\
Footpath & 4.23 & 7.35 & 2.99 \\
Unpaved Road & 25.35 & 69.12 & \\
Paved Road & 50.70 & 14.71 & \\
\hline C Use Changes & & \\
\hline
\end{tabular}

\subsection{Land Use Changes}

\subsubsection{Location I: Igboyegun Area}

The area under study does not have an existing development plan, but as of 2006 , it was revealed that $60.11 \%$ of the buildings were residential while $3.61 \%$ were commercial land uses. However, $17.42 \%$ was occupied with 
mixed-uses and $18.86 \%$ public land uses. As at 2009 , there was a reduction of residential land area as it accounts for $58.12 \%$. An increase was evident in both the commercial (4.25\%) and mixed (18.77\%) land uses. By 2012, residential area has reduced to $55.52 \%$, while commercial uses increased to $5.19 \%$. Likewise an increase was noticeable in mixed-uses as its percentage increased to $21 \%$. Public spaces and other land uses remain the same within the period. The trend in land use change at Igboyegun is such that while residential land use decreases over the years, mixed uses and commercial land uses are replacing residential land uses. There were changes in concentration of other category of land uses in the area, howbeit not tremendously as observed with residential, commercial, and mixed land uses.

In general, buildings that were originally designed as residences are now being used partly as shops, offices, and residence. Increases in solely commercial uses are not as much as mixed-uses. This is attributable to the fact that ownership structure across the study area is $57.7 \%$ for property owner and $42.3 \%$ in joint ownership. Houses owned and occupied by property owners may not change to completely commercial uses as the property owners may not leave their personal house. This reaffirms the findings made in section 3.1 on why people continue to live in this area despite observed poor living condition and poor housing facilities. Critical observation of the physical pattern of development and land uses in the area reveals uncontrolled development. The reason is not far-fetched; several scholars have argued that the area is old. Its development probably started in the period when planning activities was yet to be formally functional in the study area.

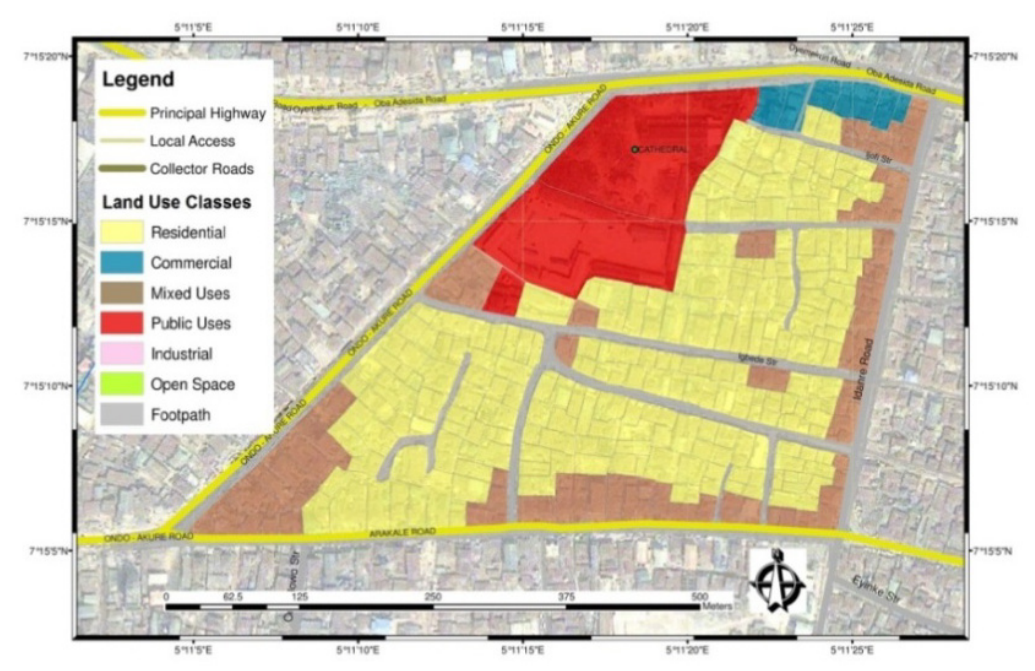

\begin{tabular}{|l|l|l|l|}
\hline Land Use & $\begin{array}{c}\text { Colour } \\
\text { Code }\end{array}$ & \multicolumn{2}{|c|}{ Year 2006 } \\
\hline & & $\begin{array}{r}\text { \% } \\
\text { Coverage }\end{array}$ & Area(sqm) \\
\hline Residential & & 60.11 & 101475 \\
\hline Commercial & 3.61 & 6095 \\
\hline Mixed Uses & 17.42 & 29399 \\
\hline Public & & 18.86 & 31839 \\
\hline Industrial & & 0.00 & 0 \\
\hline Open Space & & 0.00 & 0 \\
\hline Roads & & Constant & 116134 \\
\hline TOTAL & & & 285900 \\
\hline
\end{tabular}

Figure 3. False composite image of land use classification of Igboyegun area for 2006

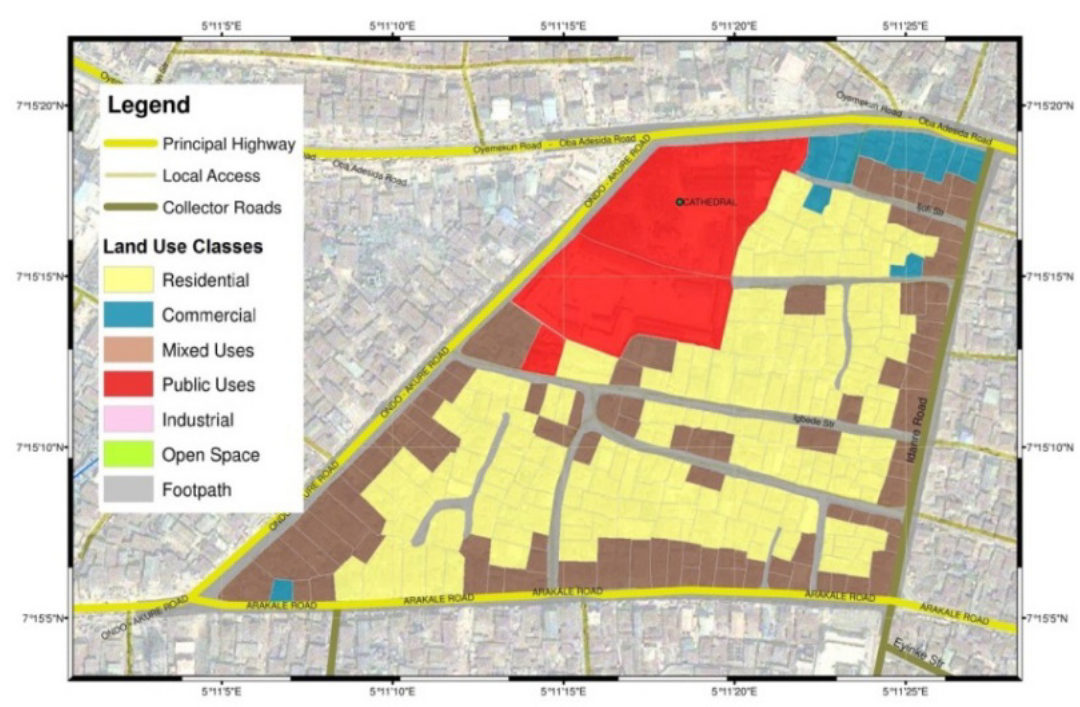

\begin{tabular}{|l|l|l|l|}
\hline Land Use & $\begin{array}{l}\text { Colour } \\
\text { Code }\end{array}$ & \multicolumn{2}{|c|}{ Year 2012 } \\
\hline & & $\begin{array}{r}\text { \% } \\
\text { Coverage }\end{array}$ & Area(sqm) \\
\hline Residential & & 55.52 & 93724 \\
\hline Commercial & & 5.19 & 8760 \\
\hline Mixed Uses & 21.00 & 35443 \\
\hline Public & & 18.86 & 31839 \\
\hline Industrial & & 0.00 & 0 \\
\hline Open Space & & 0.00 & 0 \\
\hline Roads & & Constant & 116134 \\
\hline TOTAL & & & 285900 \\
\hline
\end{tabular}

Figure 4. False composite image of land use classification of Igboyegun area for 2012 


\subsubsection{Location 11: Araromi/Odo-Ikoyi}

As of 2006, 33.87\% of development in this area was residential, $7.08 \%$ commercial and $54.13 \%$ was mixed-uses while $5.40 \%$ was for public uses. By 2009 , residential land uses had reduced significantly (by $3.27 \%$ ), to $30.60 \%$. By 2012, further reduction had occurred in the number and area for residential development to $28.04 \%$ while commercial land uses over the same period increased from $7.08 \%$ in 2006 to $15.64 \%$ in 2012 . These significant changes in land use are expected, considering that the area forms part of the commercial core of town, which is characterised by high level of activity.

In addition, this area of the core part of Akure is characterised by the location of markets e.g. Oja-Oba, Oja-Oshodi, etc and close proximity with the King's Palace, the township hall, and other notable activity centres. By implication, it will be logical to argue that influence of all these activity areas could be held accountable for the observed massive transformation in land use characteristics.

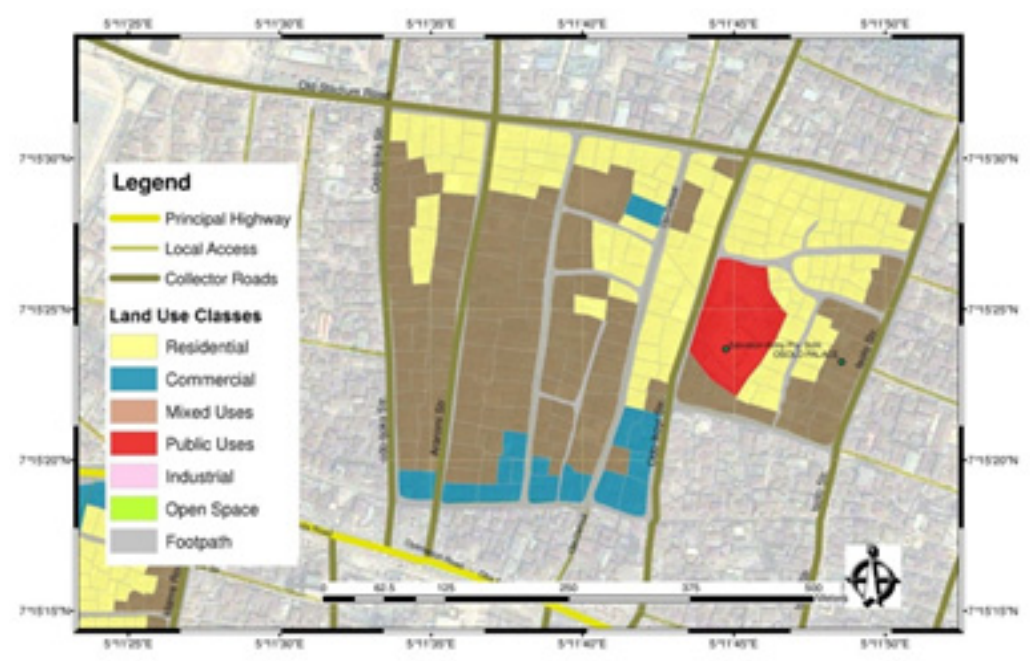

\begin{tabular}{|l|l|l|l|}
\hline Land Use & $\begin{array}{c}\text { Colour } \\
\text { Code }\end{array}$ & \multicolumn{2}{|c|}{ Year 2006 } \\
\hline & & $\begin{array}{r}\text { \% } \\
\text { Coverage }\end{array}$ & Area(sqm) \\
\hline Residential & & 33.87 & 49278 \\
\hline Commercial & & 7.08 & 10309 \\
\hline Mixed Uses & 54.13 & 78766 \\
\hline Public & & 5.40 & 7860 \\
\hline Industrial & & 0.00 & 0 \\
\hline Open Space & & 0.00 & 0 \\
\hline Roads & & Constant & 116134 \\
\hline TOTAL & & & 262347 \\
\hline
\end{tabular}

Figure 5. Land use classification of Google image of Araromi/Odo-Ikoyi area for 2006

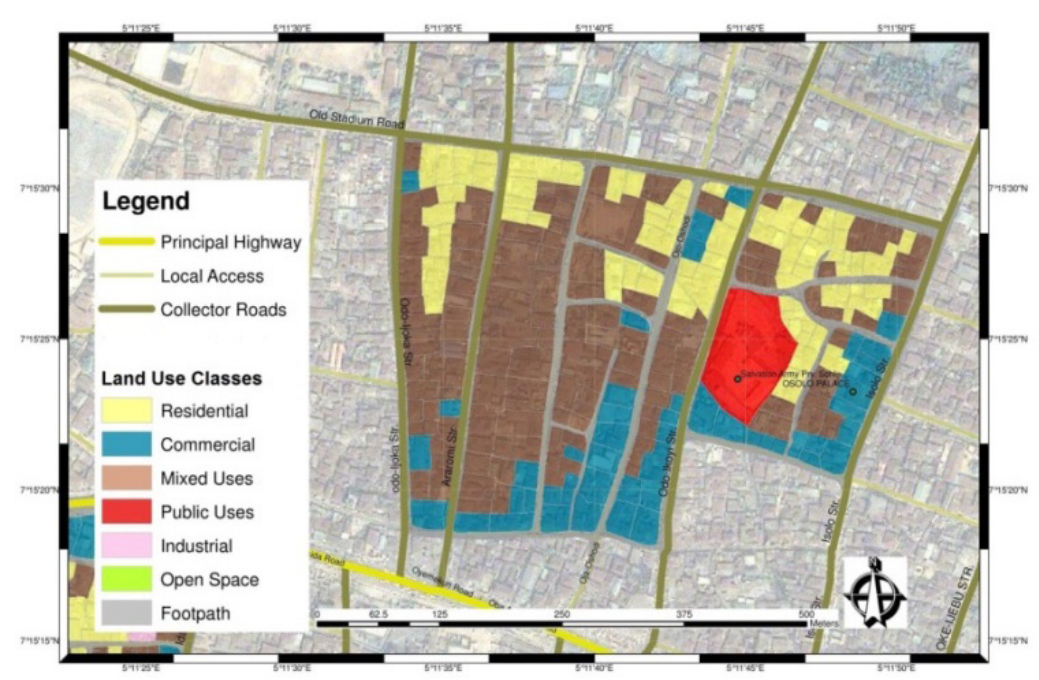

\begin{tabular}{|l|l|l|l|}
\hline Land Use & $\begin{array}{c}\text { Colour } \\
\text { Code }\end{array}$ & \multicolumn{2}{|c|}{ Year 2012 } \\
\hline & & $\begin{array}{r}\text { \% } \\
\text { Coverage }\end{array}$ & Area(sqm) \\
\hline Residential & & 28.04 & 40803 \\
\hline Commercial & & 15.64 & 22752 \\
\hline Mixed Uses & 51.70 & 75224 \\
\hline Public & & 5.40 & 7860 \\
\hline Industrial & & 0.00 & 0 \\
\hline Open Space & & 0.00 & 0 \\
\hline Roads & & Constant & 116134 \\
\hline TOTAL & & & 262347 \\
\hline
\end{tabular}

Figure 6. Land use classification of Google image of Araromi/Odo-Ikoyi area for 2012

\subsubsection{Location III: Isolo}

Findings, as presented in Figure 7, revealed that $64.01 \%$ of buildings in Isolo were serving residential purposes as at $2006,0.62 \%$ was solely for commercial purposes while $0.77 \%$ was engaged for mixed land uses. Between 2006 and 2009 , mixed land uses had increased slightly to $1.57 \%$. Presently, about $62.41 \%$ of land uses in the area are residential, commercial land uses are relatively low, and although it has increased over the years, some 
residents admitted having to go to nearby markets before they can get some category of goods. It is important to note that solely commercial land uses are few in Isolo as the area is primarily a residential area. Other land uses, for example schools, have not significantly increased in this area. Presently, about $62.41 \%$ of land uses in Isolo are residential, $2.33 \%$ are mixed uses, and about $0.72 \%$ are solely commercial uses. It is important to observe that a large percentage of open space in the area $(27.02 \%)$ is not an indication of a well-planned neighbourhood. Rather, it is because of the buffer allowed for River Ala, which passes through part of Isolo.

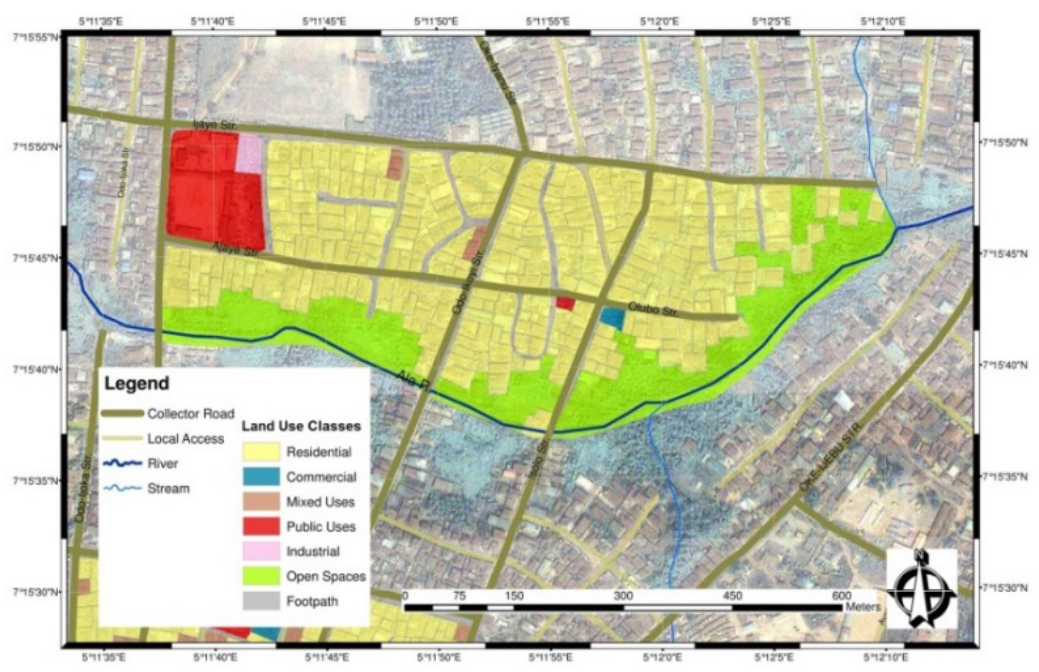

\begin{tabular}{|l|l|l|l|}
\hline Land Use & $\begin{array}{c}\text { Colour } \\
\text { Code }\end{array}$ & \multicolumn{2}{|c|}{ Year 2006 } \\
\hline & & $\begin{array}{r}\text { \% } \\
\text { Coverage }\end{array}$ & Area(sqm) \\
\hline Residential & & 64.01 & 170088 \\
\hline Commercial & & 0.62 & 1657 \\
\hline Mixed Uses & & 0.77 & 2055 \\
\hline Public & & 6.90 & 18339 \\
\hline Industrial & & 0.67 & 1787 \\
\hline Open Space & & 27.02 & 71800 \\
\hline Roads & & Constant & 116134 \\
\hline TOTAL & & & 381860 \\
\hline
\end{tabular}

Figure 7. Land use classification of Google image of Isolo Area for 2006

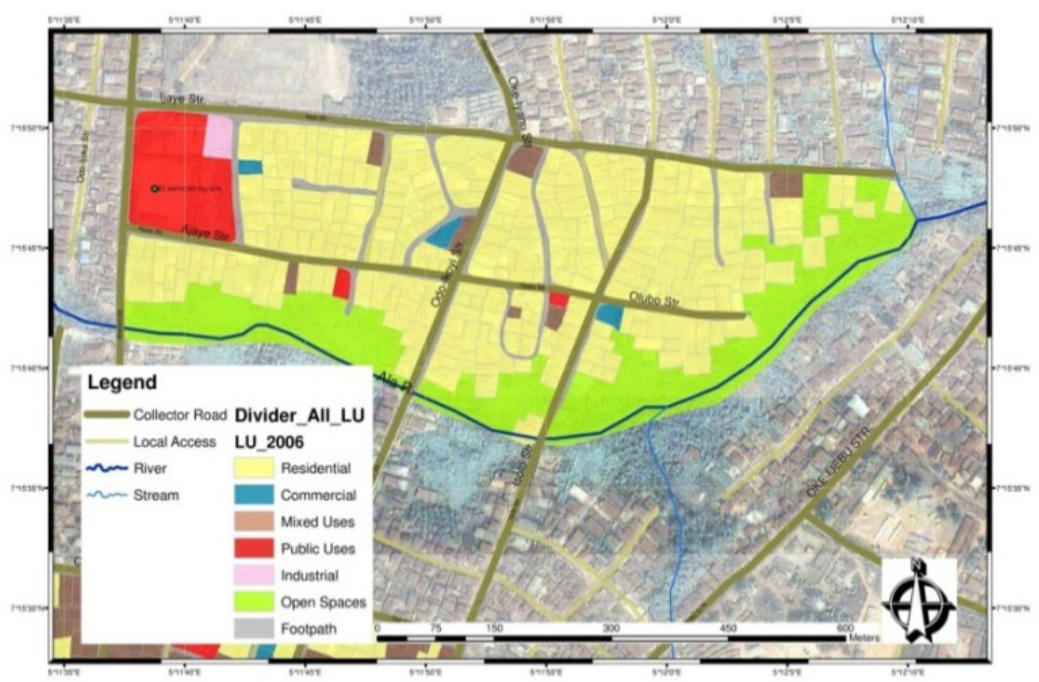

\begin{tabular}{|l|l|l|l|}
\hline Land Use & $\begin{array}{c}\text { Colour } \\
\text { Code }\end{array}$ & \multicolumn{2}{|c|}{ Year 2012 } \\
\hline & & $\begin{array}{r}\text { \% } \\
\text { Coverage }\end{array}$ & Area(sqm) \\
\hline Residential & & 62.41 & 165824 \\
\hline Commercial & & 0.72 & 1914 \\
\hline Mixed Uses & & 2.33 & 6189 \\
\hline Public & & 7.09 & 18839 \\
\hline Industrial & & 0.67 & 1787 \\
\hline Open Space & & 27.02 & 71800 \\
\hline Roads & & Constant & 116134 \\
\hline TOTAL & & & 381860 \\
\hline
\end{tabular}

Figure 8. Land use classification of Google image of Isolo Area for 2012

\subsection{Trends of Land Use Changes in the Study Area}

A One-way ANOVA statistical test was conducted to reveal which category of land uses was the most significantly affected/changed. The test revealed that land use change across the study area is significant with an F-value of 11.16. Comparison of computed means for the different land use types revealed that the most converted land use type is the residential land uses.

Table 3. One-way ANOVA Table: Nature of change in building structure

\begin{tabular}{lccl}
\hline & Df & F & Sig \\
\hline Between groups & 3 & 11.159 & .002 \\
Within Groups & 237 & & \\
Total & 268 & & \\
\hline
\end{tabular}




\subsection{Factors Responsible for Land Use Changes}

Regression analysis was conducted to reveal the significance of the influence of factors such as rent, education level of dwellers, employment status, income level, land use policies, on changes in land uses in the study area. Results indicate that employment status is the most influential factor, followed by education level. Poor level of education influences the capacity of the property owners to control the categories of use of their property. Many land/property owners do not adjudge it as improper to live in a house where some rooms are being used as shop. As such when the opportunity present itself, most of the property owners and house owners are willing to give out properties to occupants who are willing to pay higher rents, even if such a prospective occupant wants to use the residential property for commercial activities.

Table 4. ANOVA indicating the significance of the predictor variables on land use change

\begin{tabular}{|c|c|c|c|c|c|}
\hline Model & $\mathbf{R}$ & R Square & $\begin{array}{l}\text { Adjusted } \\
\text { Square }\end{array}$ & $\begin{array}{l}\text { R Std. Error of the } \\
\text { Estimate }\end{array}$ & Sig. \\
\hline 1 & .705 & .473 & .414 & .240 & .019 \\
\hline
\end{tabular}

Dependent Variable: CHANGE IN LAND USE

The result of the statistical test reveals that there is a significant relationship between the predictor variables and the change in land use. The coefficient of determination indicates that $47.3 \%$ of the variations in land use change can be explained by the predictor variables. This indicates that $52.7 \%$ can be explained by other factors. On an individual variable level contribution to land use change, results indicate that educational level contributes $11.2 \%$, employment status contributes $15.8 \%$, rent per month contributes $10.6 \%$, income level contributes $6.7 \%$ while land use policies/regulations contribute $3.0 \%$ to land use change.

\subsection{Influence of Availability of Housing Facilities on Rent}

To test for the influence of availability of housing facilities on rent in the study area, the study conducted a regression analysis.

Table 5. ANOVA indicating the influence of housing facilities on rent

\begin{tabular}{|c|c|c|c|c|c|c|}
\hline & del & Sum of Squares & df & Mean Square & $\mathbf{F}$ & Sig. \\
\hline & Regression & 4.737 & 4 & 1.184 & 1.521 & $.198^{\mathrm{a}}$ \\
\hline \multirow[t]{2}{*}{1} & Residual & 153.382 & 237 & . 779 & & \\
\hline & Total & 158.119 & 268 & & & \\
\hline
\end{tabular}

a. Predictors: (Constant), AVAILABILITY OF TOILET FACILITY, HOUSING QUALITY, ACCESS TO BUILDING, SOURCE OF WATER

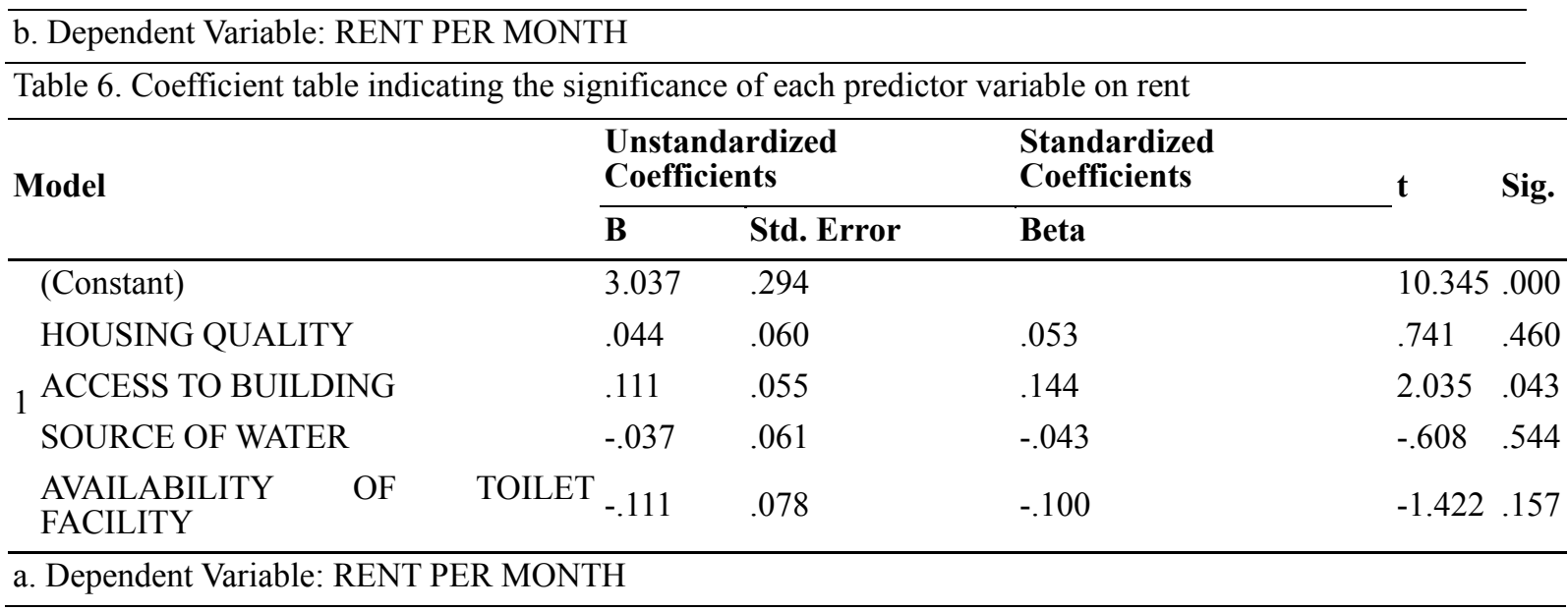


The coefficients table supplies the significance coefficient of each of the factors considered in the model. The Beta coefficient gives a rank value of significance from one factor to the other. For instance in the model, availability of ACCESS TO BUILDING (Beta $=0.144$ with 0.043 significant level) influences RENT PER MONTH the most and positively, that is the more the access the higher the rent per month in the study area.

Summarily, the model reveal that there is no significant $(p=0.198, d f=4)$ relationship between provision of housing facilities and rent in the area. That is, RENT does not increase or reduce in relation to quality of houses in the study area. The significance values for the predictors reveal that only ACCESS TO BUILDING can significantly influence RENT independently in the study area, while the other predictors do not. This means that houses on the main road attract higher rent than those not connected to the main road. It indicates that in the study area, residents care more about access to transport facility (to/from their apartments) than they care about whether their house is of durable material or not, or whether there is availability of portable water or not. This is because they have others means of catering for their water needs and condition of the house does not have a direct bearing on their income generating activities.

\subsection{Specific Slum Areas in the Studied Localities}

The UN-Habitat Expert Group Meeting (EGM) of 2008 stipulated the defining indicators for slum. One of the most important indicator is that households suffering more than one deprivation relative to the five indicators (inadequate access to safe water, inadequate access to sanitation and other infrastructure, poor structural quality of housing, overcrowding, insecure residential status) stipulated are significantly worse off than households that have no or only one deprivation. When these deprivations become characteristic of about ten (10) house units in the same vicinity, a slum can be said to exist (UN-HABITAT (EGM), 2008). Based on the above, mapping of specific slum areas across the study localities was done by aggregating the slum indicators. The characterisation result was utilized to (reveal) map out the severity of slum conditions in selected housing units, in which location with a score of 5 (sections with the darkest shades) lacks all of the thresholds while zero lacks none of the thresholds, with the rest in that order as shown in Figures 9, 10 and 11.

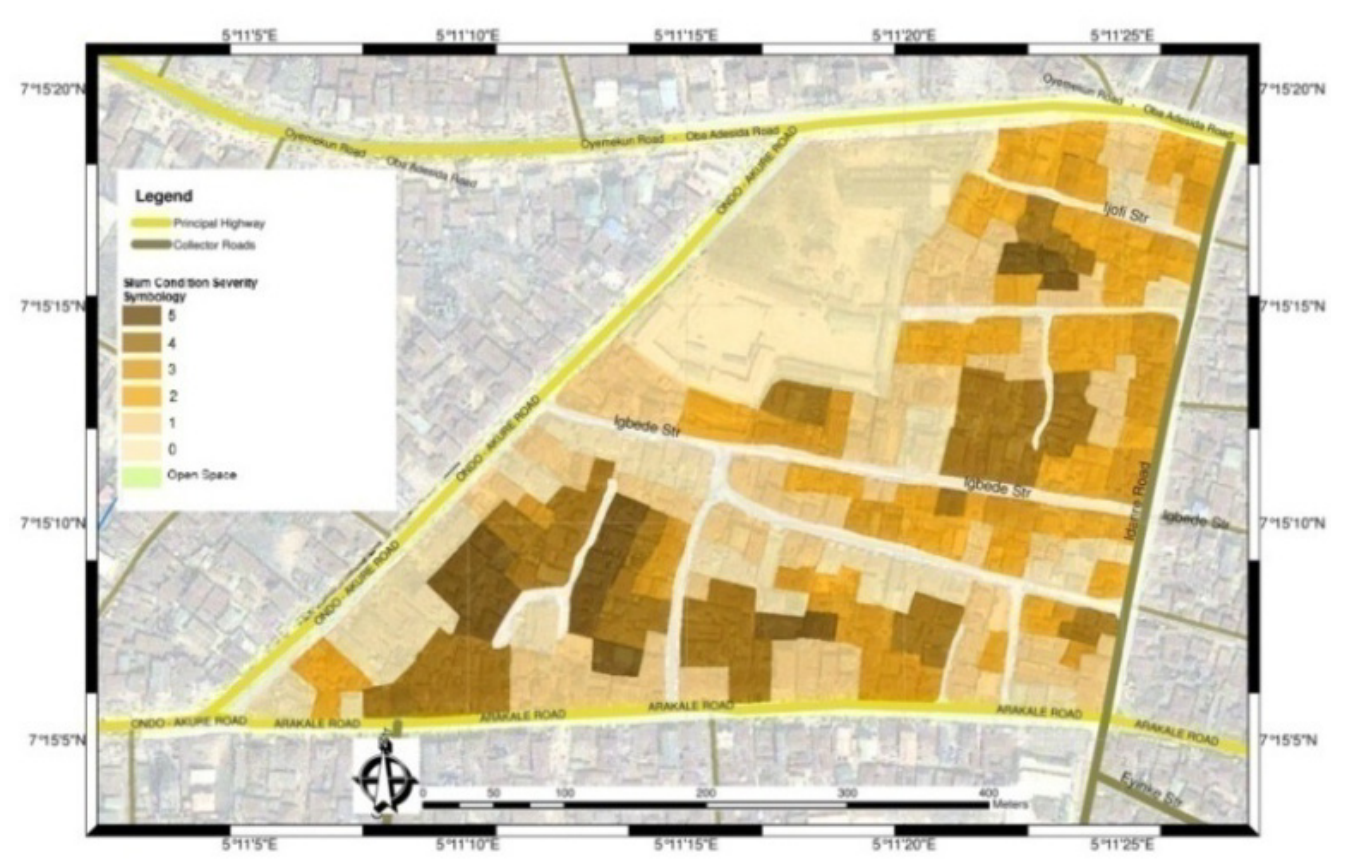

Figure 9. Specific slum areas at Igboyegun 


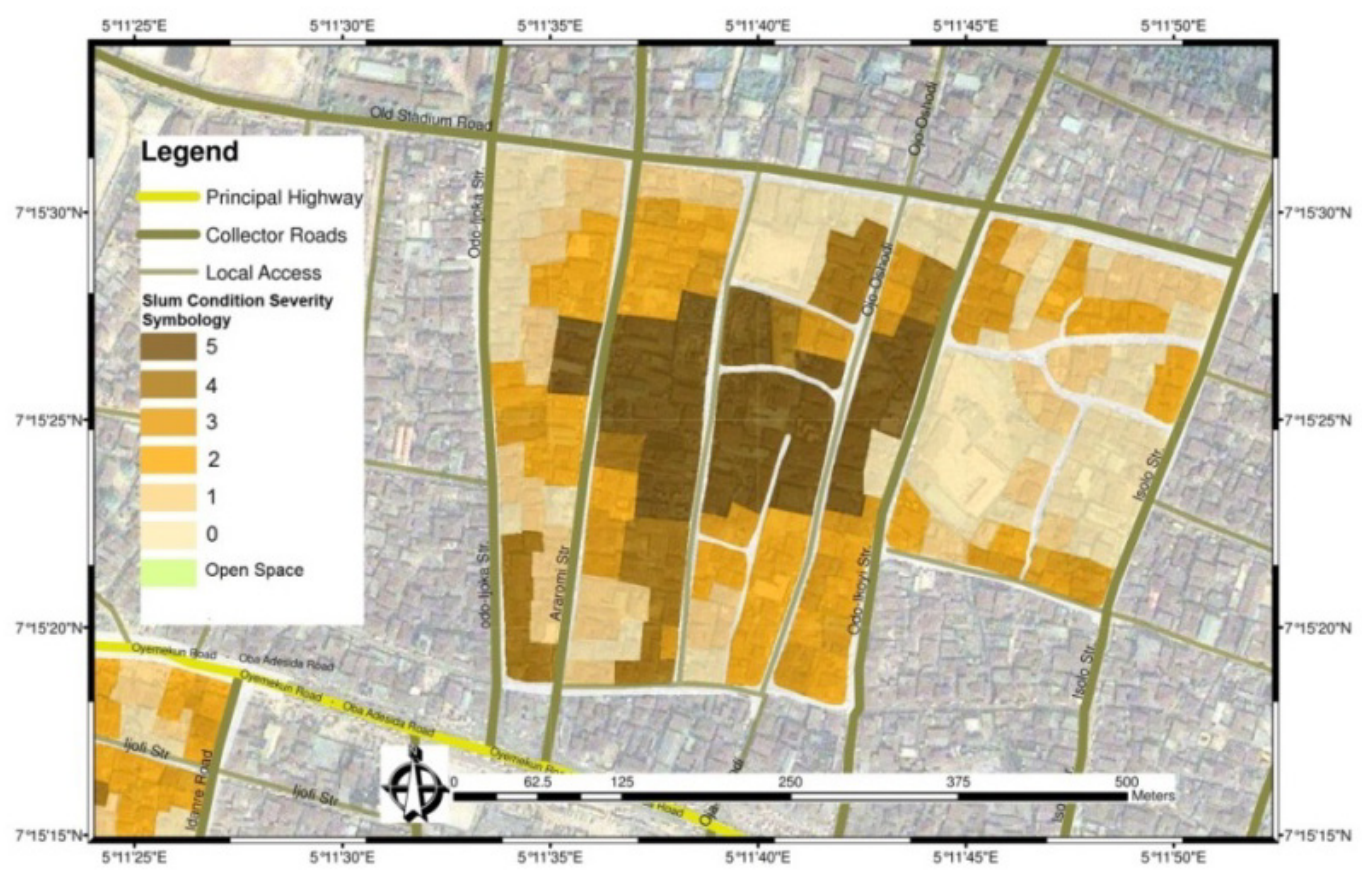

Figure 10. Specific slum areas at Araromi

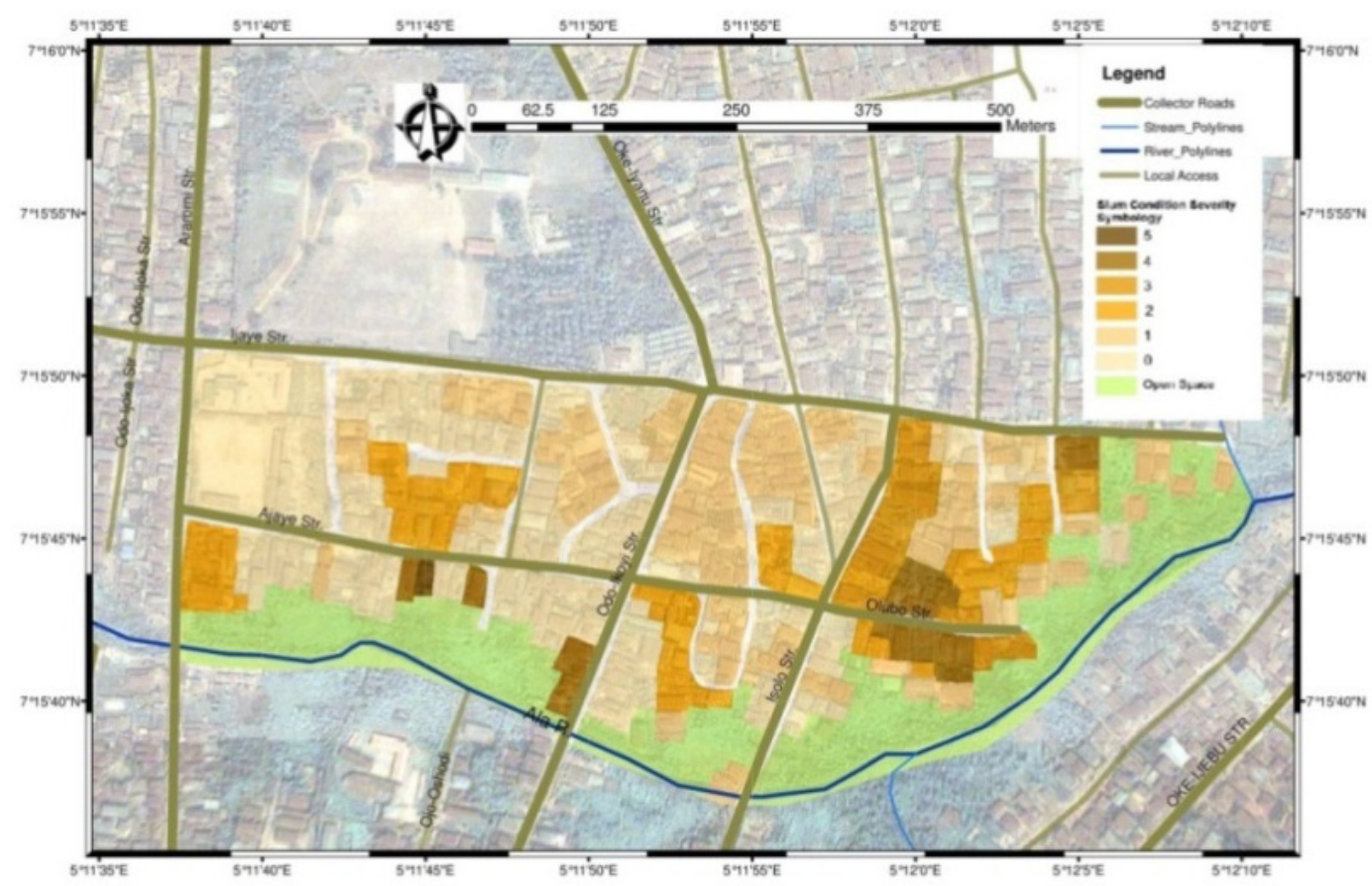

Figure 11. Specific slum areas at Isolo

The degree of deterioration of housing units, as revealed in the slum maps is not even over a slum area. There is need to decide which part of a slum area is suffering the most deterioration and dearth of facilities. GIS tools therefore constitute an effective apparatus that can be used to direct and guide actions as shown in the slum maps above. In the study area, sections or houses with higher score in deterioration reflect darker shades in the plates above. It is clear from the map that some sections of Araromi/Odo-Ikoyi require urgent attention than some sections of Isolo. 


\section{Conclusion}

The study area is not completely a slum, but sections of the area that possess attributes of slum based on relevant definitions, have been mapped in this research. The sustenance of slum in the core area of Akure is majorly due to the socio-economic situation of residents, but also related to this are the attitude of the residents to catering for their environment, healthy living and lack of enforcement/poor adherence to physical development standards.

The findings from this research show that there is high rate of change of land use and residential land uses are the most converted. The causative factor for this is high demand for spaces at the core area for businesses. The study proposes the integration of the market network strategy based on Central Place Theory of Walter Christaller to check the situation such that demand pressure is reduced on the core area and part of the bulk of business concerns in the area can be shifted from the core area. Residents should be made to show more concern on catering for the environment and efforts must be directed at enforcing development control and development standards in the area. This will help to improve the physical development of the area overtime, as the area is dynamic, in which new developments keep replacing old structures. As opined in an earlier section of this paper, efforts at remedying living conditions, economic situations, etc in slum area should vary in relation to the severity of the decay in the area. To this end, the decay severity map developed for the area will guide action in this regard, and this approach can be used to guide action in other/related situations.

Core areas are arguably the oldest part of a city. In the case of the study area, it is an area of high complexity in activities and development. Development and integration of development plan for the core areas requires meticulous planning and execution. There is need therefore to carry out studies on the methods and approach of implementation to develop and adapt development plans suitable for the sustainable growth of urban core areas in Akure and other cities in the developing countries.

\section{References}

Abbott, J. (2003). The use of GIS in informal settlement upgrading: its role and impact on the community and on local government. Habitat International, 27(4), 575-593. http://dx.doi.org/10.1016/S0197-3975(03)00006-7

Abebe, F. K. (2011). Modelling Informal settlement growth in Dar es Salaam, Tanzania. University of Twente. Faculty of Geo-Information and Earth Observation ITC, Enschede.

Ahianba, J. E., Dimuna, K. O., \& Okogun, G. R. A. (2008). Built environment decay and urban health in Nigeria. Journal of Human Ecology, 23(3), 259-265.

Akinbamijo, O. B. (2006). Predicting Urban Health Status- An Empirical Modelling Approach from Cities in Southwest Nigeria. The Social Sciences, 1(2), 133-138.

Alberti, M., \& Waddell, P. (2000). An Integrated urban development and ecological simulation model. Integrated Assessment, 1(3), 215-227. http://dx.doi.org/10.1023/A:1019140101212

Ayeni, D. A. (2012). Emphasizing Landscape Elements as Important Components of a Sustainable Built Environment in Nigeria. Developing Countries Studies, 2(8), 33-42.

Ayeni, D. A., \& Ebohon, O. J. (2012). Exploring Sustainable Tourism in Nigeria for Developmental Growth. European Scientific Journal, 8(20), 126-140.

Benz, U., Hofmann, P., Willhauck, G., Lingenfelder, I., \& 1-Ievnen, M. (2004). Multi-resolution, Object-oriented Fuzzy Analysis of Remote Sensing Data for GIS-ready Information. ISPRV Journal of Photogrammetry and Remote Sensing, 58(3-4), 239-258. http://dx.doi.org/10.1016/j.isprsjprs.2003.10.002

Christaller, W. (1966). Central Places in Southern Germany, Translated by C.W. Baskin, N.J. Englewood Cliffs as quoted by Onokeraye A.G. et. al. (1986). pp 71- 91.

Fekade, W. (2000). Deficits of Formal Urban Land Management and Informal Response Under Rapid Urban

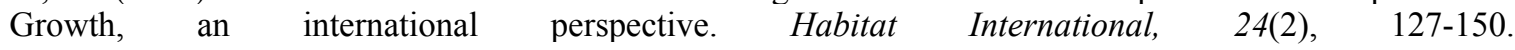
http://dx.doi.org/10.1016/S0197-3975(99)00034-X

Herold, M., Clarke, K. C., \& Seepan. (2001). Remote sensing and urban growth models-demands and perspectives. Symposium on remote sensing of urban areas, Regensburg, Germany, June 2001, Regensburger Geographische Schriften, vol 35, on supplement CD-ROM.

Hofmann, P., Strobi, J., Blaschke, T., \& Kux, I. I. (2008). Detecting informal settlements from Quickbird data in Rio de Janeiro using an object based approach. Object-Based Image.-Analysis, 531-553. http://dx.doi.org/10.1007/978-3-540-77058-9_29

Hurskainen, P., \& Pellikka, P. (2004). Change Detection of Informal Settlements Using Multi-Temporal Aerial Photographs - The Case of Voi, Se-Kenya.

Israel, G. D. (2009). Determining Sample Size. Program Evaluation and Organizational Development. IFAS, University of Florida. PEOD-6, First published November, 1992. 
Karanja, I. (2010). An Enumeration and Mapping of Informal Settlements in Kisumu, Kenya, Implemented by $\begin{array}{llll}\text { their Inhabitants. Environment and } & \text { 217-239. }\end{array}$ http://dx.doi.org/10.1177/0956247809362642

Kengne, F. F. (2000). A travers le temps et l'espace: l'irresistible expansion du secteur inform eldans les pays du sud. In F. F. Kengne, \& A. Metton (Eds.), Economic Informelle et Developement dans les pays du Sud a l'erede la Mondialisation (pp. 21-37). Yaounde:UGI/PUY.

Musaoglu, N., Kaya, S., Seker, D. Z., \& Goksel, C. (2002). A case study of using Remote Sensing Data and GIS for Land Management, Catalca Region. FLG XXII International Congress USA, Washington D.C. USA, April 19-26, 2002.

Niebergall, S, Leow A., \& Mauser, W. (2007). Object-oriented analysis of very high-resolution QuickBird data for mega city research in Delhi/India. In: Proceedings of urban remote sensing joint event 2007 (URS/URBAN), IEEE, Paris, France. http://dx.doi.org/10.1109/URS.2007.371836

Nobrega, R. A. A., Quintanilha, J. A., \& Ohara, C. G. (2006). Detecting roads in informal settlements surrounding Sao Paulo city by Using object-based classification. In proc. OBIA'06 - 1st International Conf. on Object -based Image Analysis, Salzburg - Austria.

Olujimi, J. A. B., \& Bello, M. O. (2009). Effects of Infrastructural Facilities on the Rental Values of Residential Properties. Social Sciences, 5(4), 332-341. http://dx.doi.org/10.3844/jssp.2009.332.341

Omole, F. K. (2000). Urban Renewal Process Issues and Strategies; Concept Books and Publication Company Nig. Limited, Lagos, Nigeria.

Omole, F. K., \& Owoeye, J. O. (2006). Reducing the Environmental Health-risk Factors of Slum Dwellers in Developing Country - A case study of Akure, Nigeria. Journal of Land-use and Development Studies.

Owoeye, J. O. (2006). Analysis of Slum Formation and Its Associated Effects on a Residential Core Area of Akure; An unpublished M. Tech Dissertation submitted to the Department of Urban and Regional Planning, Federal University of Technology, Akure; Nigeria.

Owoeye, J. O., \& Omole, F. K. (2012). Built Environment Decay and Health Situation of Slum Dwellers in Residential Cores of Akure, Nigeria. American Journal of Human Ecology, 1(2), 33-39.

Oyinloye, M. A., \& Kufoniyi, O. (2013). Application of GOOGLE Satellite Images in Monitoring Urban Land Use change in Ikeja, GRA, Lagos, Nigeria. International Journal of Engineering Science Invention, 2(5), $1-10$.

Ramadan, E., Peng, X., \& Cheng, Z. (2004). Satellite remote Sensing for Urban Growth Assessment in Shaoxing City, Zhejiang Province. Journal of Zhejiang University of Science, 5(9), 1095-1101. http://dx.doi.org/10.1631/jzus.2004.1095

Sartori, G., Nembrini, G., \& Stauffer, F. (2002). Monitoring of Urban Growth of Informal Settlements (IS) and Population Estimation from Aerial Photography and Satellite Imaging. Occassional paperthirstycitiesinwar.com Nairobi.

Sliuzas, R., Mboup, G., \& de Sherbinin, A. (2008). Report of the Expert Group Meeting on Slum Identification and Mapping. Report by CIESIN, UN-Habitat, ITC, 36.

Stasolla, M., \& Gamba, P. (2007). Exploiting Spatial Patterns for Informal Settlement detection in Arid Environments Using Optical Space Borne Data. International Archives of Photogrammetry, Remote Sensing and Spatial information sciences, 36 (3/W49A).

Stefanov, W. L., Ramsey, M. S., \& Christensen, P. R. (2001). Monitoring Urban Land Cover Change: An Expert System Approach to Land Cover Classification of Semi-arid to Arid Urban Centers. Remote Sensing of Environment, 77, 173-185. http://dx.doi.org/10.1016/S0034-4257(01)00204-8

UN-HABITAT. (2007). Sustainable Urbanization: Local Action for Urban Poverty Reduction, Emphasis on Finance and Planning. Twenty First Session of the Governing Councill16 - 20 April 2007, Nairobi, Kenya.

Weeks, J. R., Hill, A., Stow, D., Getis, A., \& Fugate, D. (2007). Can we spot a neighbourhood from air? Defining neighbourhood structure in Accra, Ghana. Geo Journal, 69(1-2), 9-22. http://dx.doi.org/10.1007/s10708-007-9098-4

World Bank. (2005). Global strategy and booster programme. Annual Review, 32.

\section{Copyrights}

Copyright for this article is retained by the author(s), with first publication rights granted to the journal.

This is an open-access article distributed under the terms and conditions of the Creative Commons Attribution license (http://creativecommons.org/licenses/by/3.0/). 